
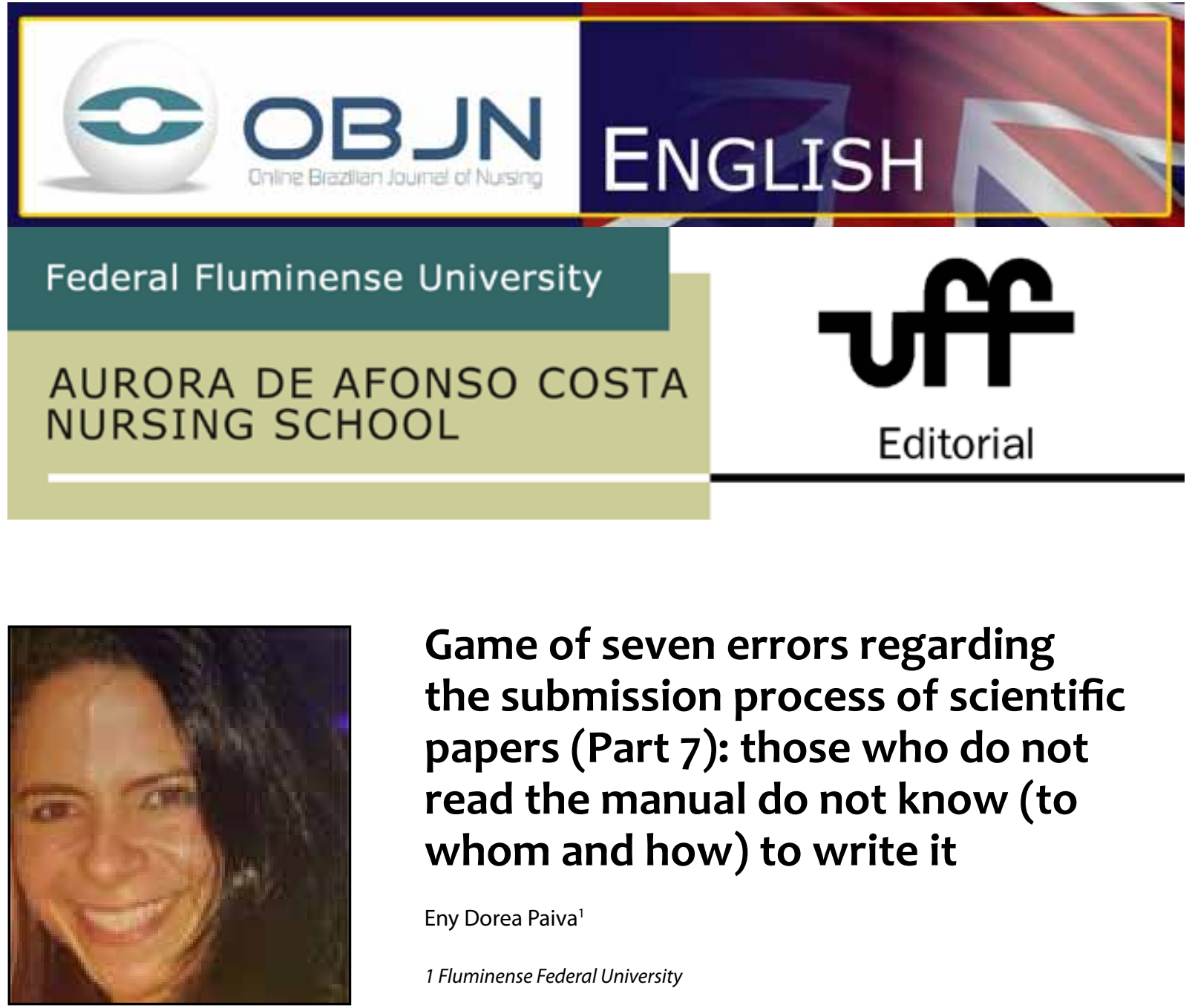

\title{
Game of seven errors regarding the submission process of scientific papers (Part 7): those who do not read the manual do not know (to whom and how) to write it
}

Eny Dorea Paiva'

1 Fluminense Federal University

\section{ABSTRACT}

To end the game of seven errors regarding the submission process of scientific papers, this editorial discusses the importance of reading the rules of journals and the publication of manuscripts. Regarding the article submission, first, it is imperative that the authors know the scope of the magazines to which they will submit the results of their studies. Any author can offer a scientific paper to be reviewed for publication in a magazine; however, these authors should read the rules for submission of manuscripts and follow them. In order to facilitate the process of publishing articles, the OBJN offers on its homepage, tutorials to instruct authors, and the creation of a new submission section entitled Research Notes, aiming at the publication of short research articles with the presentation of their partial results. It is, therefore, important that authors read thoroughly the publication standards in order to facilitate the preparation of their manuscripts and consequent publication of the results of their studies.

Descriptors: Research Design; Publication Formats; Evidence-Based Nursing. 
Intentionality, thoroughly discussed in scholastic philosophy, and more recently assimilated into the phenomenology of Edmund Husserl, brings harmony between faith and reason. When authors submit a manuscript to a journal, they bring, even if subliminally, the same concepts. The entry submit derives from the Latin'submitter':"lower, reduce, master," from SUB, "below", and MITTERE, "send, let go."That is, submitting a material to another, implies being in line with the standards established by the recipient. Thus, the basic assumption on which submitting to something means being submissi$\underline{v e}$, does not allow any questioning beyond the decision of submitting or not.

To end the Game of Seven Errors in the scientific paper submission process, this editorial discusses the importance of reading the rules of journals and publication of manuscripts. It is important to ratify and clarify that the comments that were lectured on this subject are not prioritized according to the importance or chronologically linked; however, they should not be overlooked ${ }^{(1)}$.

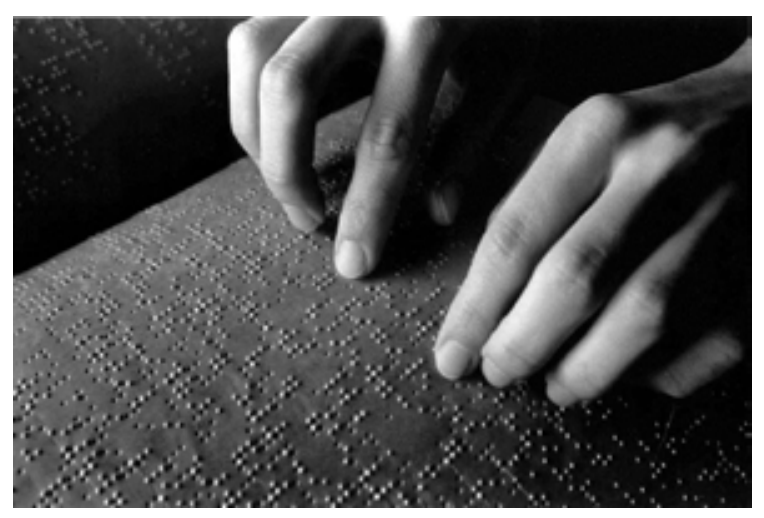

Regarding the article submission, first, it is imperative that the authors know the scope of the magazines to which they will submit the results of their studies. Any author can offer a scientific paper to be reviewed for publication in a magazine; however, they must read the submission rules for of manuscripts and follow them.
These standards are published in the magazine and the homepage ${ }^{(2)}$.

For the biomedical journals, these standards were first established in 1978 by a group of medical journal editors met in Vancouver, Canada, and published in 1979. Over the years, in addition to the article preparation standards, the committee added other documents, called separate statements, primarily related to the ethical principles that should guide the review process and publication of the manuscript ${ }^{(2)}$. In its latest version ${ }^{(3)}$, the document contains, not only detailed instructions on how authors should prepare and submit their manuscripts, but also ethical considerations concerning the conduction and reporting of the research, such as: a) authorship of the work; b) role of the publisher; c) definition of a magazine with arbitration by peers; d) conflict of interest between reviewer, author and editor, for example, involving research funding or academic competition that might influence the evaluation of the manuscript; e) the right of patients and study participants to privacy; f) the obligation to publish studies with negative results; g) correction and retraction of the author; h) copyright; i) redundant publication; j) manuscript containing conflicting interpretations of the authors on the study; $k$ ) list of magazines with advertisers and the media.

In this context and given the flow of information, simplicity to update and ease of publication, more qualified professionals involved in the process of caring, searching, managing and teaching are expected. Thus, one of the key points for the scientific material submission is the understanding of the process. For this reason, in 2011, the OBJN brought the remodeling of the rules of publication in order to meet the contemporary demands and international requirements ${ }^{(4)}$.

In the same year authors conducted a study aimed at analyzing the rules on ethics 
in research, contained in the guidelines of Brazilian scientific journals in nursing. A partial analysis of the editorial policy of these journals was carried out in this study with regard to ethics, and found that the guidelines of the section Instructions to Authors are, in most magazines, the only way of communication between authors and publishers. Therefore one can conclude that the policy adopted by the periodic reflected in these instructions, is of great importance in terms of the practice of publishing scientific papers ${ }^{(5)}$.

We can highlight the promotion of significant changes in the general rules for submission and publication of papers in scientific journals, aiming at a continuous improvement in the process. Thus, periodicals become a vehicle for publishing quality work that significantly impact on national and international research ${ }^{(6)}$. The demand for qualified publications resulting from postgraduate studies, has led authors to publish their work in the form of full papers in journals and scientific conferences ${ }^{(7)}$.

The publication of articles is a requirement for any professional who crave to be in tune with the world of science. Likewise, the consumption and production of knowledge are activities related to their work ${ }^{(8)}$.

At this juncture, in order to publish the results of their studies, authors should know the scope of the journals and thoroughly read the manuscript submission standards. However, it is observed that authors have difficulties in meeting the standards, either by not reading or by not understanding what has been read, negatively influencing the speed of the article submission process. The director of the Edanz Group, Daniel McGowan, during the workshop "How to Write for and Get Published in Scientific Journals" held by FAPESP and scientific publisher Springer, reports that one of the major challenges to be overcome by the researchers is the lack of understanding on how a scientific article should be structured ${ }^{(9)}$.

In order to facilitate the article publication process, OBJN offers on its homepage, tutorials to instruct authors, describing means standards for formatting and submitting manuscripts, the submission of sections, the editorial flow, metadata form for the articles accepted, Single Ethics Declaration Document (DUDE), among other tutorials. However, despite the description of the processes, it is observed that the authors did not meet the standards described, such as changes using the font in red, respecting the documents submissions deadlines, loading a new document in the version of the author, not as a supplementary document, among others, thus influencing the process speed.

In 2016 the OBJN will introduce a new submission section entitled Brief Communication for research results publication with an only goal. The introduction is unnecessary and the number of words is limited, aiming at reducing costs and time of the publishing process. This type of section is a trend in renowned journals publishing quality scientific papers ${ }^{(10)}$. Naturally, a new section implies specific standards and therefore attention before writing. After all, those who do not read the manual do not know (to whom and how) to write it!

\section{REFERENCES}

1. Lima DVM. Spot the seven errors. Playing the game in the submission of scientific papers (Part 1): the horse and the carrot. Online braz $\mathrm{j}$ nurs [Internet]. 2014 March [Cited 2015 Dec 22]; 13 (1): 1-4. Available from: http://www.objnursing. uff.br/index.php/nursing/article/view/4635. doi: http://dx.doi.org/10.5935/1676-4285.20144635

2. Pittella JEM. O processo de submissão, avaliação e publicação de artigos no Jornal Brasileiro de Patologia e Medicina Laboratorial. J. Bras. Patol. Med. 
Lab. [Internet]. 2012 June [cited 2015 Dec 22]; 48( 3 ): 160-162. Available from:http://www.scielo.br/scielo.php?script=sci_arttext\&pid=S1676$-24442012000300002 \& \operatorname{lng}=e n$. http://dx.doi. org/10.1590/S1676-24442012000300002

3. International Committee of Medical Journal Editors [homepage]. Recommendations for the Conduct, Reporting, Editing, and Publication of Scholarly Work in Medical Journals [internet]. [s.l]; 2014. [cited 2015 Dec 22]. Available from: http:// www.icmje.org/icmje-recommendations.pdf .

4. Lima DVM. Contributions to nursing publications: a today's challenge. Online braz j nurs [Internet]. 2011 October [Cited 2015 Dec 22]; 10 (2): . Available from: http://www.objnursing.uff.br/index. php/nursing/article/view/3649. doi:http://dx.doi. org/10.5935/1676-4285.20113649

5. Moro JV, Rodrigues JSM, André SCS. Research involving human beings in instructions to authors in domestic scientific nursing magazines. Rev. Bioética [internet]. 2011 [cited 2015 Dec 22]; 19(2): 543 - 52. Available from: http://revistabioetica.cfm.org.br/index.php/revista_bioetica/ article/view/643/690.

6. Moreno MEF. Buenas prácticas en la publicación de artículos científicos. Aquichán [internet] 2015 [cited 2015 Dec 22]; 15 (2): 174-175. Available from: http://www.scielo.org.co/pdf/aqui/v15n2/ v15n2a01.pdf DOI: 10.5294/aqui.2015.15.2.1

7. Soares ABB. Novidades em nossas normas para submissão e publicação de artigos. Rev. Bras. Eng. Biom. [internet] 2013 Mar [cited 2015 Dec 22]; 29 (1): 1-2. Available from: http://www.scielo.br/ pdf/rbeb/v29n1/a01v29n1.pdfDOl: http://dx.doi. org/10.4322/rbeb.2013.011
8. Kirchhof ALC, Lacerda MR. Desafios e perspectivas para a publicação de artigos - uma reflexão a partir de autores e editores. Texto contexto enferm. [Internet]. 2012 Mar [cited 2015 Dec 22]; 21(1): 185-193. Available from: http://www.scielo. br/scielo.php?script=sci_arttext\&pid=S0104-07072012000100021\&lng=en. DOI: http:// dx.doi.org/10.1590/S0104-07072012000100021)

9. Fundação de Amaparo à Pesquisa do Estado de São Paulo [homepage]. Especialistas dão dicas para a publicação de artigos científicos [internet]. São Paulo; 2012. [cited 2015 Dec 22]. Available from:http://agencia.fapesp.br/especialistas_dao_dicas_para_a_publicacao_de_artigos_cientificos/15344/

10. The Journal of Neuroscience [homepage]. Brief Communications: overview [internet]. Standford; [s.d.]. [cited $2015 \mathrm{Dec} 22$ ]. Available from: http:// www.jneurosci.org/site/misc/ifa_bc.xhtml

\section{IMAGE REFERENCE}

Casadaptada. [sem título].[fotografia] [s.l.];[s.d.]. [cited 2015 Dec 22]. Avalable from: http://www.casadaptada.com.br/2015/05/ braile-facil/

Received: $11 / 22 / 2015$

Approved: 12/22/2015 